\title{
Gyulladás vagy daganat?
}

\section{Egy hirtelen jelentkezö lateralis cysticus nyaki terime tanulságai}

\author{
Major Tamás dr. ${ }^{1}$ - Szarka Krisztina dr. ${ }^{2}$ - Nagy Zsófia ${ }^{2}$ \\ Kovács Ilona dr. ${ }^{3}$ - Balog Csaba dr. ${ }^{4}$ Karosi Tamás dr. ${ }^{5}$ \\ ${ }^{1}$ Debreceni Egyetem, Klinikai Központ Kenézy Gyula Campus, \\ Fül-Orr-Gége, Fej- és Nyaksebészeti Osztály, Debrecen \\ ${ }^{2}$ Debreceni Egyetem, Általános Orvostudományi Kar, Klinikai Központ, Orvosi Mikrobiológia, Debrecen \\ ${ }^{3}$ Debreceni Egyetem, Klinikai Központ Kenézy Gyula Campus, Patológiai Osztály, Debrecen \\ ${ }^{4}$ Borsod-Abaúj-Zemplén Megyei Központi Kórház és Egyetemi Oktatókórház, \\ Klinikai Onkológiai és Sugárterápiás Centrum, Miskolc \\ ${ }^{5}$ Borsod-Abaúj-Zemplén Megyei Központi Kórház és Egyetemi Oktatókórház, \\ Fül-Orr-Gége és Fej-Nyak Sebészeti Osztály, Miskolc
}

\begin{abstract}
A lateralis cysticus nyaki terimék két leggyakoribb oka a branchiogen cysta és a cysticus nyaki áttét. Az átfedő lokalizáció (a leggyakrabban a IIA nyaki régióban), a betegek életkora és az esetenként hirtelen kezdet alapján a két leggyakoribb ok differenciáldiagnózisa nagy kihívást jelenthet. Egy hirtelen fellépő fájdalmas, bal oldali nyaki duzzanattal, dysphagiával és lázzal jelentkező 72 éves férfi esetét ismertetjük. A nyak komputertomográfiás vizsgálata egy $6 \mathrm{~cm}$ legnagyobb átmérőjú, vastag falú, többrekeszes cysticus terimét igazolt. Infektív branchiogen cysta lehetőségére gondolva az elváltozást eltávolítottuk. A szövettan azonban pl6-pozitív laphámrákot igazolt. A primer tumort végül az ipsilateralis tonsilla palatina állományában sikerült azonosítani. A beteg definitív radioterápiában részesült, és 18 hónappal a diagnózis után tumormentes. A nyaki cystákon, az infektív nyaki cystákon és a cysticus metastasisokon kívül a humán papillómavírussal összefüggő szájgarati laphámrákok infektív cysticus vagy necroticus metastasisait is figyelembe kell venni a lateralis cysticus nyaki terimék differenciáldiagnózisában.
\end{abstract}

Orv Hetil. 2020; 162(15): 595-600.

Kulcsszavak: fej-nyaki laphámrák, humánpapillómavírus-fertőzés, metastasis, branchiogen cysta, tályog, differenciáldiagnózis

\section{Inflammatory or malignant?}

\section{Lessons from a cystic lateral neck lesion with a sudden onset}

Branchial cleft cysts and cystic neck metastases are the two most common causes of cystic lateral neck masses. Based on the overlapping location (neck level IIA), patient age at onset and the occasionally sudden onset, their differential diagnosis is challenging. We present a 72 -year-old male presenting with a suddenly emerging painful, left-sided neck swelling, dysphagia and fever. Computed tomography showed a $6 \mathrm{~cm}$ thick-walled multicystic mass. With the suspected diagnosis of an infected branchial cleft cyst, the lesion was removed. Histology confirmed pl6 positive squamous cell carcinoma. Primary tumor was identified in the ipsilateral palatine tonsil. Definive radiotherapy was performed and the patient is free of disease at the 18-month follow-up. Beyond pure and infected branchial cleft cysts and pure cystic metastases, infected cystic or necrotic metastasis of human papillomavirus associated oropharyngeal squamous cell carcinoma should be included in the differential diagnosis of cystic lateral neck lesions.

Keywords: squamous cell carcinoma of head and neck, human papillomavirus infection, metastasis, branchial cleft cyst, abscess, differential diagnosis

Major T, Szarka K, Nagy Zs, Kovács I, Balog Cs, Karosi T. [Inflammatory or malignant? Lessons from a cystic lateral neck lesion with a sudden onset]. Orv Hetil. 2021; 162(15): 595-600.

(Beérkezett: 2020. október 17.; elfogadva: 2020. október 29.) 


\section{Rövidítések}

$\mathrm{CRP}=\mathrm{C}$-reaktív protein CT $=($ computed tomography $)$ komputertomográfia; DNS $=$ dezoxiribonukleinsav; FDG $=18 \mathrm{~F}$ fluor-dezoxi-glükóz; HPV = humán papillómavírus; $\mathrm{PCR}=$ (polymerase chain reaction) polimeráz-láncreakció; $\mathrm{PET}=$ pozitronemissziós tomográfia; SUV = (standardized uptake value $)$ standardizált felvételi érték; TNM = tumor, nodus, metastasis

A cysticus lateralis nyaki terimék két legfóbb oka a branchiogen cysta és a cysticus nyaki metastasis [1]. A branchiogen cysták, melyek a leggyakrabban a második kopoltyútasak embrionális maradványaiból vagy egy nyaki nyirokcsomóban lévő laphámzárványokból származnak, általában a 2 . vagy a 3 . évtizedben a IIA régióban (a felső parajugularis régiónak a nervus accessorius előtti része) tapintható terime formájában jelentkeznek $[2,3]$. Az időskorban, akár a 7. évtizedben jelentkező branchiogen cysta már irodalmi ritkaság [3]. Az esetek mintegy harmadában - felülfertőződés következtében a branchiogen cysta hirtelen jelenik meg $[3,4]$.

Cysticus nyaki metastasis a leggyakrabban a Waldeyergyưrü laphámrákjaihoz (ezen esetek 33-50\%-ában jellemző), jóval ritkábban papillaris pajzsmirigy-carcinomához vagy a nyelőcső laphámrákjaihoz társul [5]. A szájgarati laphámcarcinomák cysticus nyaki metastasisa humán papillómavírussal (HPV) társult jelenség, melyet a metastasisok HPV-DNS in situ hibridizációs vizsgálata és a pl6 immunhisztokémiai vizsgálata során észlelt 87100\%-os pozitivitás igazol $[5,6]$. A szájgarati laphámrákoknak napjainkban 70-90\%-a pozitív HPV-DNS kimutatására irányuló tesztekkel vagy pl6-immunhisztokémiával, és ez az arány a fejlett országokban drámai növekedést mutat $[5,7]$. A HPV-asszociált szájgarati laphámrákban szenvedő beteg - a HPV-negatív esetekkel összehasonlítva - jellemzően fiatal fehér férfi, élete során több szexuális partnerrel és minimális vagy hiányzó dohányos anamnézissel. Egy amerikai egyesült államokbeli tanulmány szerint azonban 1995 és 2013 között a 65 évnél idősebb, szájgarati laphámrákos betegek között a HPV-asszociált esetek prevalenciája 41\%-ról 75\%-ra, a betegek átlagéletkora pedig a diagnózis idején 53 évről 57 évre nőtt [8]. A HPV-asszociált szájgarati tumorok esetében a hirtelen kialakuló nagy cysticus nyaki metastasishoz sokszor kicsiny vagy okkult primer tumor társul. Ezen metastasisok rapid („overnight”) kialakulását a nyirokáramlás hirtelen elzáródása okozhatja [5]. A HPV-asszociált szájgarati tumorok manifeszt és okkult metastasisainak jellemző lokalizációja egyaránt a IIA nyaki régió [9].

Az életkorban és a lokalizációban mutatkozó átfedések miatt a branchiogen nyaki cystáknak a HPV-asszociált okkult szájgarati laphámrákok solitaer cysticus metastasisától történő elkülönítése igen nehéz feladat. Branchiogen nyaki cystával operált felnőttek esetén a laphámrák szövettani diagnózisának valószínúsége 3-24\%, mely az életkor előrehaladtával nő [6]. A lateralis nyaki cysták és ritkábban a metastasisok is felülfertőződhetnek, tovább nehezítve a diagnózist.

Jelen kazuisztikánkban egy kezdetben okkult, HPVasszociált szájgarati carcinoma hirtelen kialakult cysticus metastasisát mutatjuk be, mely egy mély - a felületes nyaki fascia alatt elhelyezkedő - nyaki tályogot utánzott.

(a)
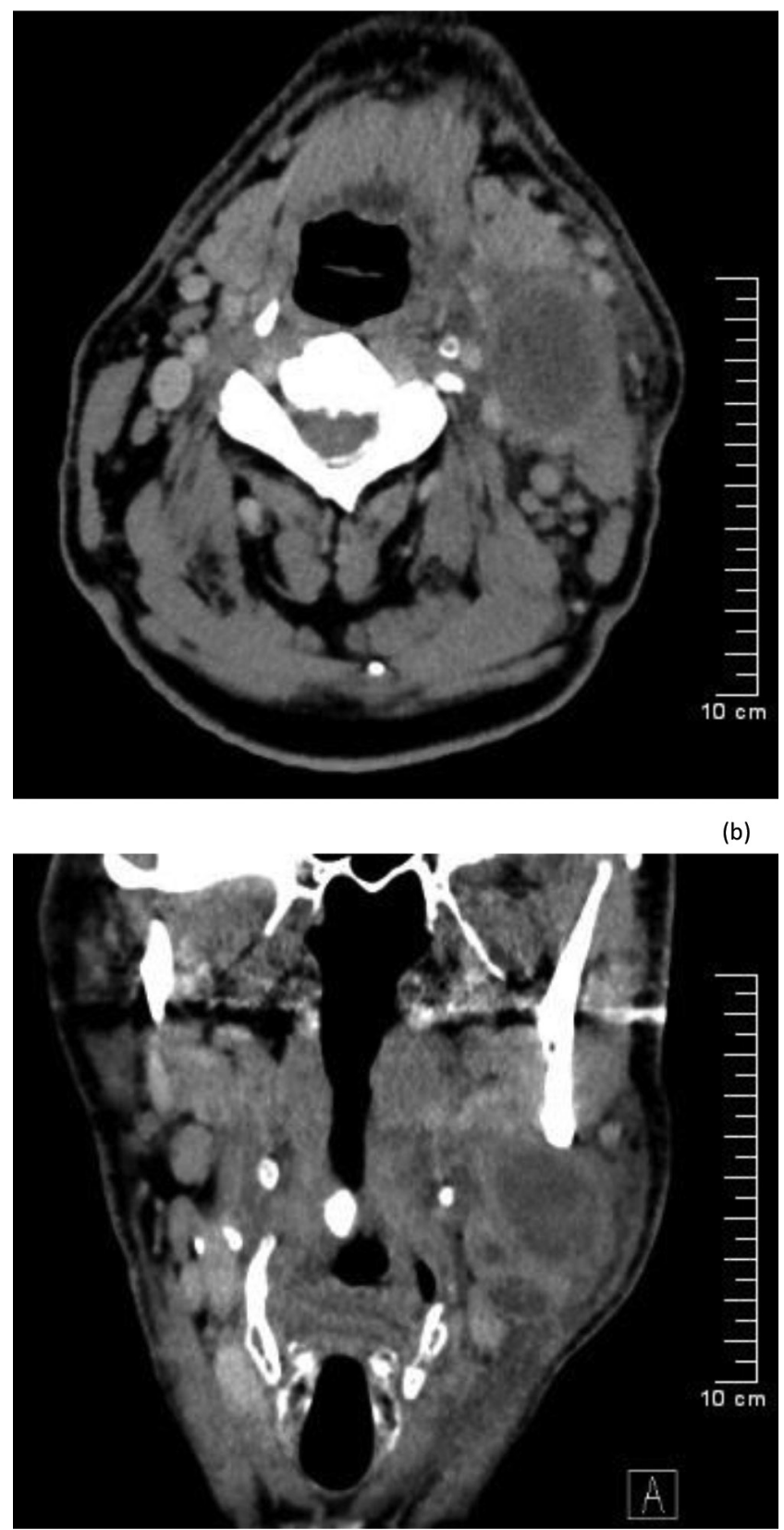

1. ábra

A nyaki terime kontrasztanyag adása utáni vénás fázisú CT-képe. (a) Az axiális képeken egy kontraszthalmozó kerettel rendelkező cysticus terime látható a bal oldali II. régióban, mely a musculus sternocleidomastoideus és a glandula submandibularis szomszédságában helyezkedik el. (b) A koronális képeken egy $60 \times$ $40 \mathrm{~mm}$-es multicysticus terime ábrázolódik a bal II. és III. régióban, mely egy nagyobb cranialis és két kisebb caudalis, széli részeiken kontraszthalmozó hypodensitasokból áll. Szembetúnő a bal szájgarati és algarati oldalfal oedemája és medializációja

CT = számítógépes tomográfia 


\section{Esetismertetés}

2019 nagypéntekjén egy 72 éves, nem dohányzó, alkoholt rendszeresen nem fogyasztó férfi beteg 4 napja észlelt, hirtelen kialakult, fájdalmas bal oldali nyaki duzzanat, dysphagia és láz miatt jelentkezett a Borsod-AbaújZemplén Megyei Központi Kórház és Egyetemi Oktatókórház Fül-Orr-Gége és Fej-Nyak Sebészeti Osztályának ügyeletén. A fizikális vizsgálat során a bal II. és III. régióban egy $8 \mathrm{~cm}$ legnagyobb átmérôjü, nyomásérzékeny, fluktuáló terimét és a bal oldalsó szájgarati fal enyhe medializációját észleltük. A tonsilla palatina és a nyelvgyök állományában körülírt terime nem volt tapintható. A nasalisan bevezetett flexibilis eszközzel végzett endoszkópia során a fentieken túl enyhe bal oldali algarati és gégebemeneti oedemát észleltünk. Laborleletei közül az emelkedett fehérvérsejtszám (14,6 G/l) neutrophiliával $(83,3 \%)$ és a C-reaktív protein (CRP) emelkedett értéke $(126,27 \mathrm{mg} / \mathrm{l})$ emelendő ki. A nyaki lágyrészek komputertomográfiás (CT-) vizsgálata a bal oldali II. és III. ré-

(a)

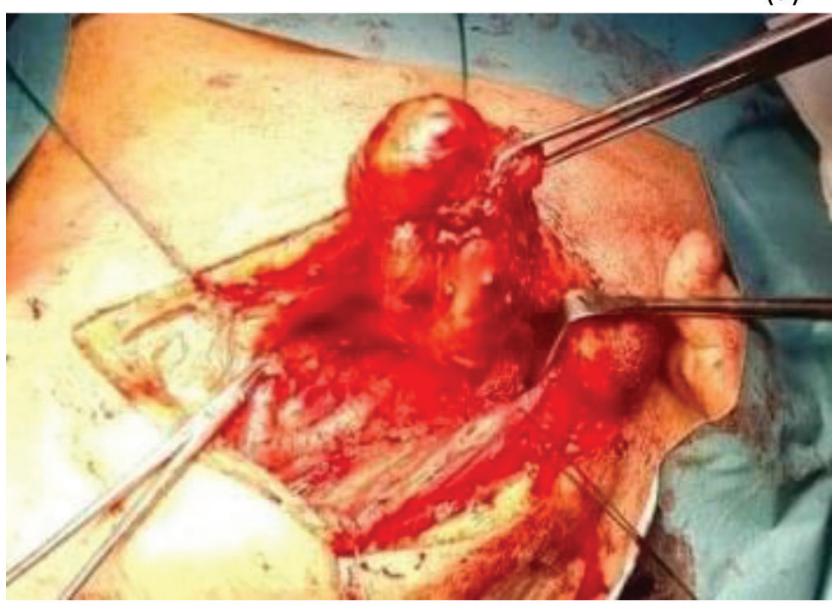

(b)

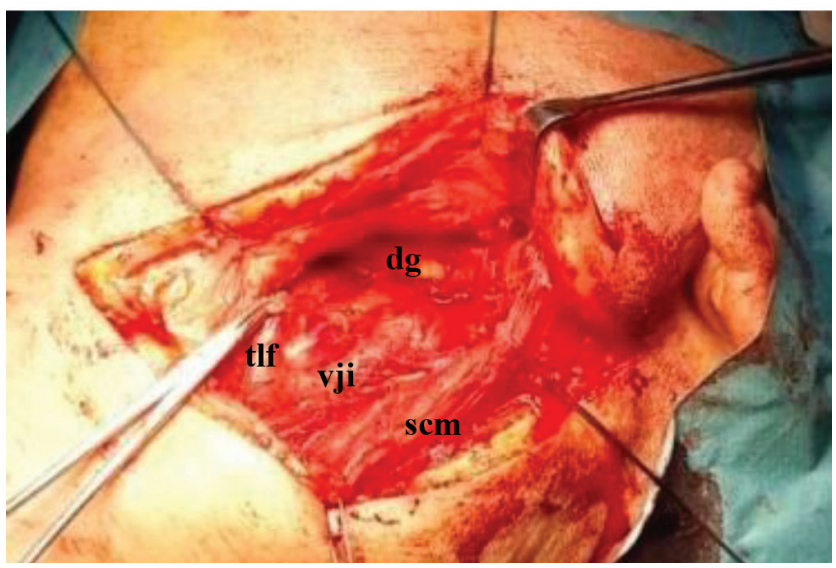

2. ábra gióra lokalizálódó, $60 \times 40 \times 30$ mm-es, többrekeszes cysticus terimét igazolt (l. ábra).

A nyelési nehezítettséget és fenyegető légúti elzáródást okozó, lymphadenitis talaján kialakult mély nyaki tályog vagy infektív branchiogen cysta valószínú diagnózisa miatt a külső nyaki feltárás mellett döntöttünk. Ennek során a II. és III. (felső és középső parajugularis) régióra lokalizálódó, vastag falú cysticus terimét akadálytalanul el tudtuk választani a vagina caroticától és a környező oedemás lágyrészektől (subcutan zsír, platysma, musculus [m.] sternocleidomastoideus és $\mathrm{m}$. digastricus) (2. ábra). Az alkalmazott empirikus, kombinált intravénás antibiotikumkezelés (amoxicillin/klavulánsav és metronidazol) mellett a beteg láztalanná vált, a garatfali medializáció és az algarati-gégebemeneti oedema meg-

(a)

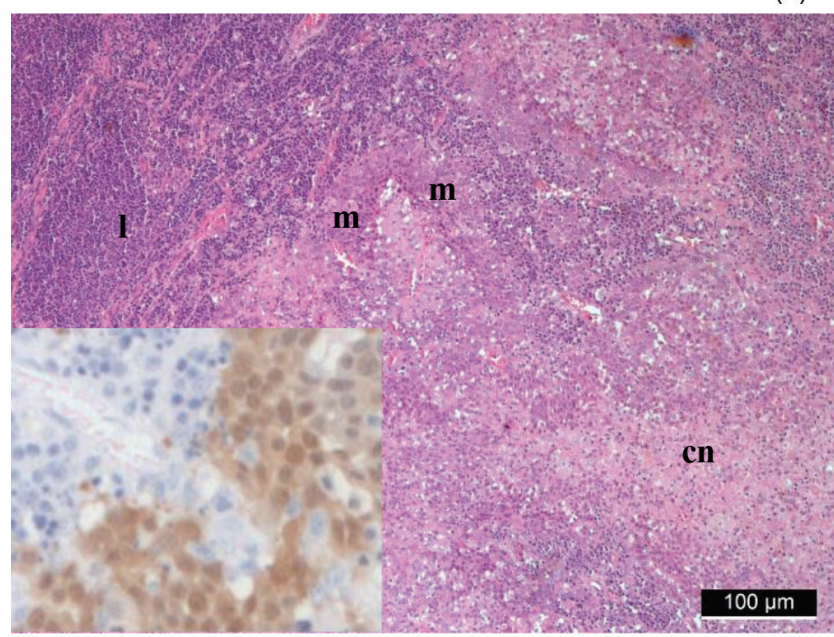

(b)

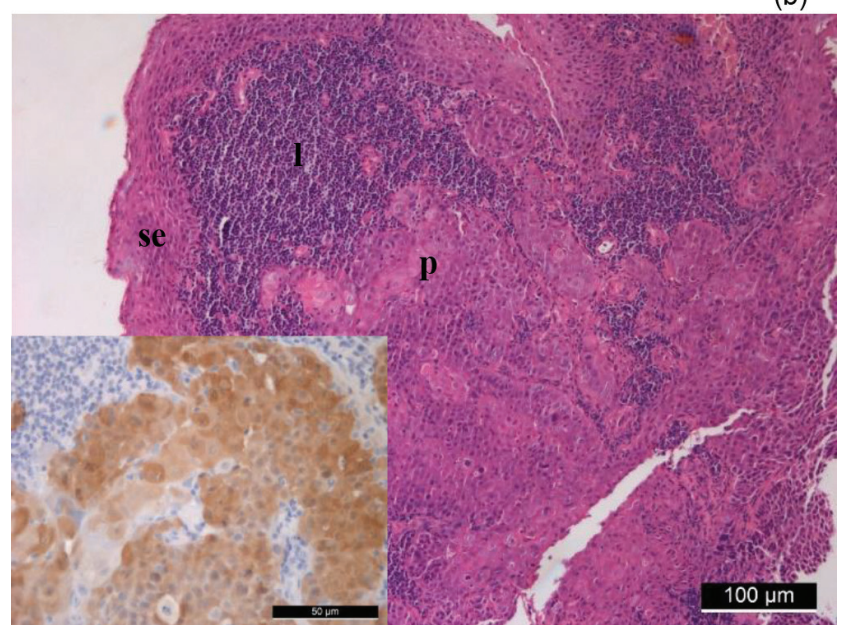

3. ábra

Az eltávolított nyaki terime (a) és a később igazolt, azonos oldali szájgarati primer tumor (b) szövettani lelete. Az ábrán a metastaticus nyirokcsomó (a) és a bal tonsilla palatinából kiinduló primer, el nem szarusodó laphámrák (b) képe látható (HE, $\times 100$ ). Mindkét lokalizációban beillesztettük a pl6-immunhisztokémia nagy nagyítású $(\times 400)$ képét is, mely a metastasis (a) és a primer tumor (b) esetén is erős és diffúz nukleáris és citoplazmatikus pozitivitást igazol

$\mathrm{cn}=$ centrális necrosis $; \mathrm{HE}=$ hematoxilin-eozin $; \mathrm{l}=$ nyirokszö vet; $\mathrm{m}=$ metastaticus laphámcarcinoma; $\mathrm{p}$ = primer laphámcarcinoma; se = felszíni epithelium 
szűnt, a fehérvérsejtszám és a CRP-érték csökkent, így az 5. posztoperatív napon a beteget hazaengedtük.

A makroszkópos patológiai leírás egy sưrű szürkészöld bennékű, $60 \times 25 \times 30 \mathrm{~mm}$-es cysta volt. A szövettani vizsgálat azonban el nem szarusodó laphámcarcinomát, az utólagos pl6-immunhisztokémia erős ( $\geq 70 \%)$ és diffúz nukleáris és citoplazmatikus pl6-festődési mintázatot igazolt (3. ábra, a). Az ezt követően narkózisban végzett felső légúti pánendoszkópia (az orrüreg, a garat, a gége és a nyelőcsőbemenet vizsgálata) során malignitásra utaló eltérést nem észleltünk, azonban a bal tonsilla palatinaállományából vett biopszia igazolta a primer tumort (3. ábra, b). A 18F-fluor-dezoxi-glükóz adásával végzett pozitronemissziós tomográfia/komputertomog- ráfia (FDG-PET/CT) a bal tonsilla állományában egy 28 $\mathrm{mm}$, a bal oldali III. régióban egy $10 \mathrm{~mm}$ legnagyobb átmérőjü, FDG-halmozó laesiót írt le (4. ábra). A HPV16 E7-es régiójára specifikus polimeráz-láncreakció (PCR) mind a primer tumorban, mind a metastasisban igazolta a HPV16 DNS jelenlétét [10].

A III. stádiumú, residualis, HPV-társult szájgarati laphámcarcinomára (rT2N1M0) vonatkozó aktuális ajánlás (National Comprehensive Cancer Network, Head and Neck Cancer Guidelines) alapján az intézményi fej-nyaki onkológiai tanácsadó testület definitív radioterápiát javasolt. A 18 hónapos kontroll fizikális és képalkotó vizsgálatok (nyaki lágyrész- és mellkas-CT) alkalmával a beteg tumormentesnek bizonyult. (a)

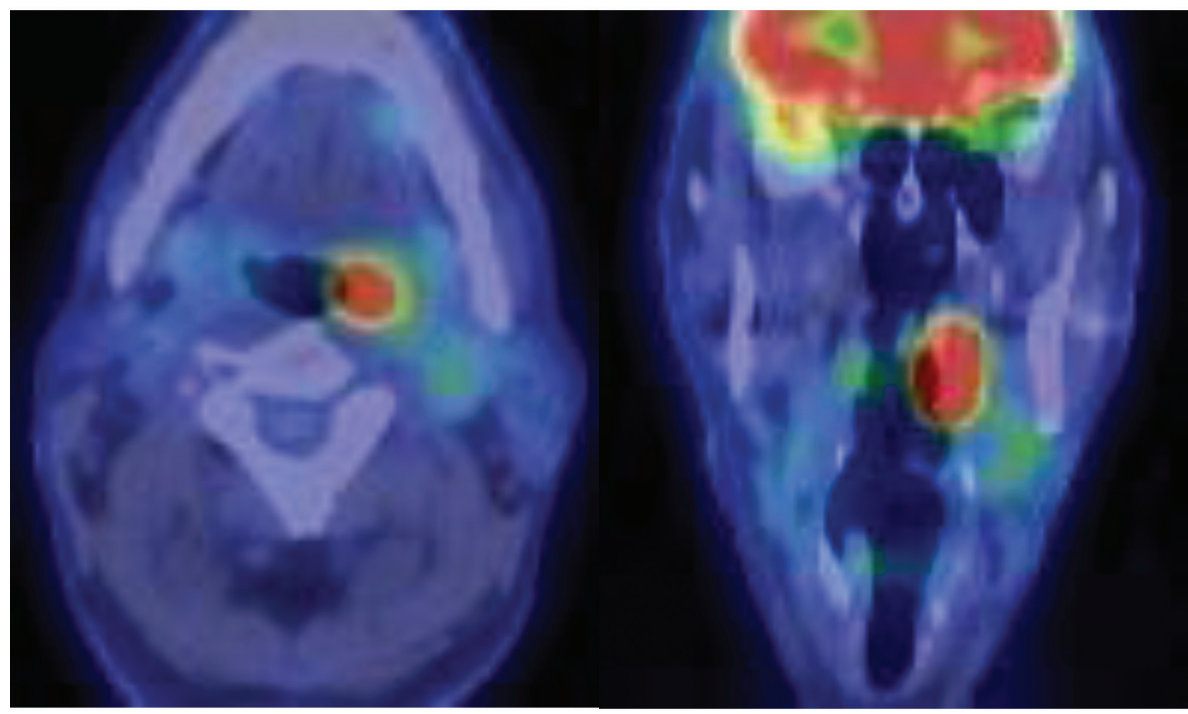

(c)

(d)

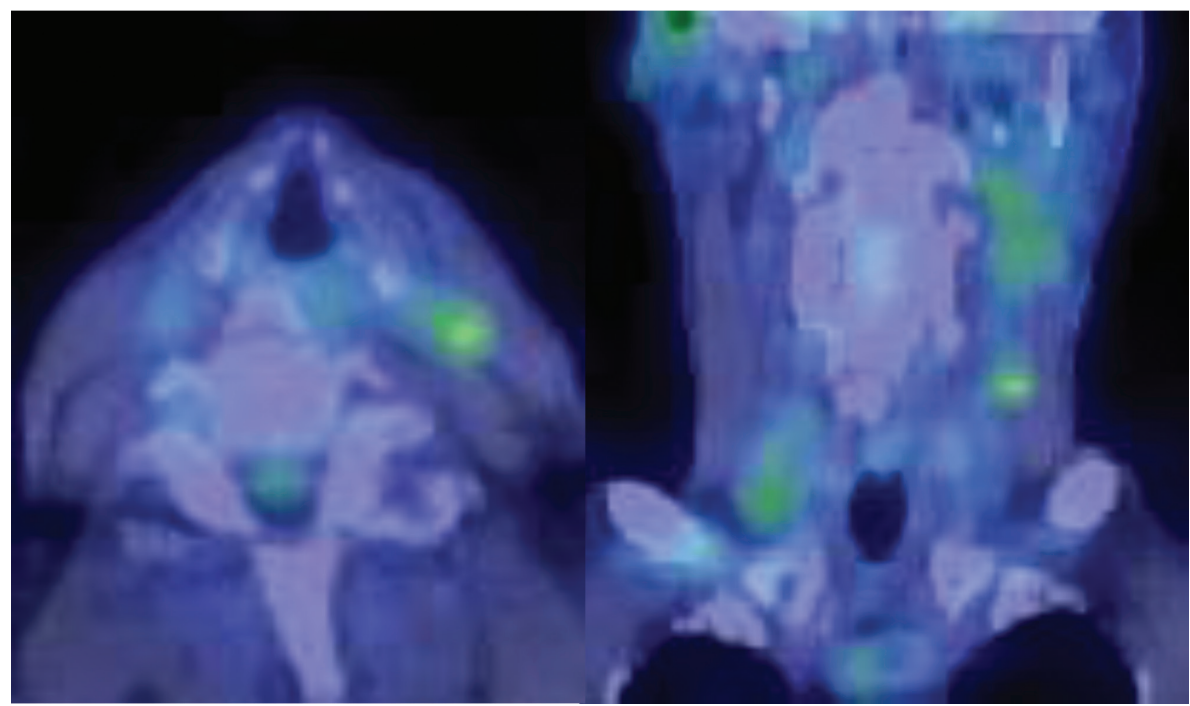

4. ábra

A definitív irradiáció elótti FDG-PET/CT-lelet. A bal tonsilla palatina állományában az axiális képen (a) 17 mm átmérójü, a koronális képen (b) 28 $\mathrm{mm}$ craniocaudalis átmérőjú FDG-halmozó laesio látható $\left(\mathrm{SUV}_{\max } 13,4\right)$. A nyakon a III. régióban az axiális (c) és a koronális képen (d) egyaránt residualis metastaticus nyirokcsomónak megfelelő, $10 \mathrm{~mm}$ átmérőjú, FDG-halmozó terime, továbbá a II-III. régiónak megfelelően a posztoperatív állapotnak megfelelő diszkrét FDG-halmozás látható

$\mathrm{CT}$ = komputertomográfia; FDG = 18F-fluor-dezoxi-glükóz; PET = pozitronemissziós tomográfia 


\section{Megbeszélés}

Esetünk is bizonyítja, hogy a malignitás lehetôségével minden felnőttkori lateralis cysticus nyaki terime esetén számolni kell, még akkor is, ha a gyulladásos eredetre utaló kezdeti diagnózis (infektív branchiogen cysta vagy lymphadenitis) egyértelmúnek túnik. A cysticus metastasis akaratlan eltávolításának következménye a sebgyógyulás zavara, a regionális recidíva nagyobb valószínúsége és a betegségspecifikus túlélési idő csökkenése lehet [6]. Ennek elkerülésére a 40 év feletti betegek esetében az utóbbi évtizedben számos diagnosztikai algoritmust dolgoztak ki, melyek részei a preoperatív radiológiai és citopatológiai vizsgálat, a nyaki terime intraoperatív gyorsfagyasztott szövettani értékelése, továbbá az ezzel egy ülésben a tonsillectomiával, a nyelvgyökból és az orrgaratból vett térképbiopsziákkal és ezek szintén gyorsfagyasztott szövettani feldolgozásával kiegészített pánendoszkópia $[1,6,11]$. Ha ezen diagnosztikai algoritmusok alapján malignitás igazolható, egy ülésben a nyaki dissectio is elvégzendő [11]. Esetünkben akár a preoperatív finomtú-aspirációs biopszia, akár a citológiai sejtblokkokból végzett pl6-immunhisztokémia igazolhatta volna a metastaticus etiológiát. Mivel a beteg egy négynapos ünnep első napján jelentkezett, az előbbi diagnosztikai lehetőségek nem álltak rendelkezésünkre. A sürgős mútéti indikáció azonban - tekintettel a gégebemeneti oedemára - egyértelmú volt. A terime méretére, szerkezetére és a környező szervekhez való viszonyának megítélésére primer képalkotó eljárásnak a CT-t választottuk (1. ábra).

A branchiogen cysták és a cysticus metastasisok esetében a CT-morfológiában is vannak átfedések, azonban a branchiogen cysták jellemzően nagyobbak, szerkezetük homogén, bennékük inkább sugáráteresztő, faluk vékony, jól körülhatárolt, belső septumok jelenléte nem jellemző. Két vagy több confluens csomó jelenléte inkább metastasisra utal [12]. Ugyanakkor a vastagabb fal és a keretszerú kontrasztanyag-halmozás infektív cystára és centrálisan necroticus metastasisra egyaránt utalhat $[1,3,4]$. Betegünk CT-filmjét ismételten áttekintve az elmosódott határú egyenetlen külső falak és a centrális heterogenitás utalhat malignitásra. Az eredetileg leírt többrekeszes cysta valójában több confluens nyirokcsomó lehet (1. ábra, b).

A mély nyaki tályogot utánzó metastasis ritkaság [13, 14]. Egy 439, mély nyaki tályogos beteget felölelő retrospektív monocentrikus tanulmányban malignitás mindössze 8 esetben igazolódott, a primer tumor lokalizációjára azonban a szerzők nem tértek ki [13]. Ismereteink szerint esetünk az első HPV-társult szájgarati tumormetastasis a szakirodalomban, mely mély nyaki tályogot utánzott. A tályogképződés patomechanizmusa nem tisztázott. A már meglévő cysticus metastasis esetén a gennykeltó baktériumok forrása lehet maga a kifekélyesedett primer tumor [15]. Más esetekben a metastasisban lezajló centrális necrosis utánoz suppurativ lympha- denitist [16]. A cysticus metastasis és a centrális necrosis két külön entitás [11]. A cysticus metastasis oka lehet akár a nyirokcsomóban lévő keratin spontán degradációja révén létrejövő pseudocystás elváltozás, akár a nyirokcsomó centrumában lévő neoplasticus hámból kialakuló valódi cysta [5]. A centrális necrosis ugyanakkor a gyors tumornövekedés következménye [11]. Esetünkben a nyaki terime etiológiája mint infektív cysticus vagy centrálisan necroticus metastasis nem állapítható meg egyértelmúen, bár a hisztopatológiai lelet inkább az utóbbi lehetôség mellett szól.

A TNM-kézikönyv aktuális, 8. kiadásában leírtak értelmében ismeretlen primer tumor esetén a folyamat Epstein-Barr-vírus vagy HPV kimutatására immunhisztokémiai vizsgálat szükséges [17]. Esetünkben a pl6-immunhisztokémia erős és diffúz nukleáris és citoplazmatikus festődést mutatott. A második ülésben elvégzett, biopsziával kiegészített pánendoszkópia során a primer tumor az azonos oldali tonsilla palatinában igazolódott.

A kezdetben okkult primer tumorral ellentétben, a sugártervezéshez végzett FDG-PET/CT már T2-es méretú elváltozást mutatott. Ennek oka lehet az első jelentkezéskor a kicsiny primer elváltozást elfedő gyulladásos oedema, az első jelentkezés és az FDG-PET/CT között eltelt 6 hetes intervallum, továbbá a primer tumor gyors növekedése is. A nyakon a III. régióban leírt, $10 \mathrm{~mm}$-es FDG-halmozó terime residualis nyirokcsomó-metastasisnak felel meg, mely a szövettani vizsgálattal metastasisnak bizonyult terime inadekvát mütétének szemléletes példája.

\section{Következtetés}

A noninfektív branchiogen cystákon és a cysticus nyaki metastasisokon túl, a lateralis cysticus nyaki terimék differenciáldiagnosztikáját a mély nyaki tályog képében jelentkező infektív branchiogen cysták és az infektív vagy centrálisan necroticus metastasisok is cizellálják. 40 éven felül minden lateralis cysticus nyaki terimét malignusnak tartunk mindaddig, amíg annak ellenkezőjét nem sikerül bizonyítani. Ehhez egy következetesen végigvitt diagnosztikai algoritmus szükséges, mely a preoperatív képalkotó és citopatológiai vizsgálatból, a nyaki terime intraoperatív gyorsfagyasztott szövettani értékeléséből, továbbá az ezzel egy ülésben a tonsillectomiával, a nyelvgyökből és az orrgaratból vett térképbiopsziákkal és ezek szintén gyorsfagyasztott szövettani feldolgozásával kiegészített pánendoszkópiából áll. Így nagy valószínúséggel elkerülhető egy cysticus metastasis akaratlan eltávolítása, mely elhúzódó sebgyógyulással, a regionális recidíva nagyobb valószínúségével és a betegségspecifikus túlélési idő csökkenésével járhat.

Anyagi támogatás: A közlemény megírása, illetve a kapcsolódó kutatómunka anyagi támogatásban nem részesült. 
Szerzôi munkamegosztás: M. T.: A beteg klinikai diagnózisa, mútéte, a kézirat megírása. Sz. K., N. Zs.: A HPVDNS-tipizálás elvégzése. K. I.: A pl6 immunhisztokémiai vizsgálatok értékelése. B. Cs.: A fej-nyaki onkológiai tanácsadó testület vezetőjeként a beteg onkológiai ellátásának koordinálása. K. T.: A beteg klinikai diagnózisa, a kézirat szerkesztése. A cikk végleges változatát valamennyi szerző elolvasta és jóváhagyta.

Érdekeltségek: A szerzőknek nincsenek érdekeltségeik.

\section{Irodalom}

[1] Yehuda M, Schechter M, Abu-Ghanem N, et al. The incidence of malignancy in clinically benign cystic lesions of the lateral neck: our experience and proposed diagnostic algorithm. Eur Arch Otorhinolaryngol. 2018; 275: 767-773.

[2] Robbins K, Clayman G, Levine P, et al. Neck dissection classification update: revisions proposed by the American Head and Neck Society and the American Academy of Otolaryngology - Head and Neck Surgery. Arch Otolaryngol Head Neck Surg. 2002; 128: 751-758.

[3] Sira J, Makura ZG. Differential diagnosis of cystic neck lesions. Ann Otol Rhinol Laryngol. 2011; 120: 409-413.

[4] Pietarinen-Runtti P, Apajalahti S, Robinson S, et al. Cystic neck lesions: clinical, radiological and differential diagnostic considerations. Acta Otolaryngol. 2010; 130: 300-304.

[5] Goldenberg D, Begum S, Westra WH, et al. Cytic lymph node metastasis in patients with head and neck cancer: an HPV-associated phenomenon. Head Neck 2008; 30: 898-903.

[6] Koch EM, Fazel A, Hoffmann M. Cystic masses of the lateral neck - Proposition of an algorithm for increased treatment efficiency. J Craniomaxillofac Surg. 2018; 46: 1664-1668.

[7] Paver EC, Currie AM, Gupta R, et al. Human papilloma virus related squamous cell carcinomas of the head and neck: diagno- sis, clinical implications and detection of HPV. Pathology 2020; 52: 179-191.

[8] Windon MJ, D'Souza G, Rettig EM, et al. Increasing prevalence of human papillomavirus-positivie oropharyngeal cancers among older adults. Cancer 2018; 124: 2993-2999.

[9] Plonowska KA, Strohl MP, Wang SJ, et al. Human papillomavirus-associated oropharyngeal cancer: patterns of nodal disease. Otolaryngol Head Neck Surg. 2019; 160: 502-509.

[10] Evander M, Wadell G. A general primer pair for amplification and detection of genital human papillomavirus types. J Virol Methods 1991; 31: 239-250.

[11] Franzen A, Günzel T, Buchali A, et al. Cystic lateral neck lesions: etiologic and differential diagnostic significance in a series of 133 patients. Anticancer Res. 2019; 39: 5047-5052.

[12] Goyal N, Zacharia TT, Goldenberg D. Differentiation of branchial cleft cysts and malignant cystic adenopathy of pharyngeal origin. Am J Roentgenol. 2012; 199: W216-W221.

[13] Wang LF, Tai CF, Kuo WR, et al. Predisposing factors of complicated deep neck infections: 12-year experience at a single institution. J Otolaryngol Head Neck Surg. 2010; 39: 335-341.

[14] Lee WC, Walsh RM, Tse A. Squamous cell carcinoma of the pharynx and larynx presenting as neck abscess or cellulitis. J Laryngol Otol. 1996; 110: 893-895.

[15] Thorp MA, Carrie S. Neck abscess: an unusual presentation of a thoracic malignancy. J Laryngol Otol. 1998; 112: 891-892.

[16] Soon SR, Kanagalingam J, Johari S, et al. Head and neck cancers masquerading as deep neck abscesses. Singapore Med J. 2012; 53: 840-842.

[17] Brierley JD, Gospodarowicz MK, Wittekind C. (eds.) TNM classification of malignant tumours. 8th edn. Wiley Blackwell, Oxford, 2017.
(Major Tamás dr., Debrecen, Bartók Béla út 2-26., 4031 e-mail: major.tamas@kenezy.unideb.hu)

Az Orvosi Hetilap 2021; 162: 400. oldalán (10. szám) megjelent OH-kvízre két helyes megfejtés érkezett.

A beküldők: Dr. Bíró László (Budapest) és Dr. Kónya Csaba (Budapest).

A nyerteseknek szívből gratulálunk.

Nyereményüket - egy, az Akadémiai Kiadó webáruházában

kedvezményes vásárlásra jogosító kupont - e-mailen küldjük el.

A cikk a Creative Commons Attribution 4.0 International License (https://creativecommons.org/licenses/by/4.0/) feltételei szerint publikált Open Access közlemény, melynek szellemében a cikk bármilyen médiumban szabadon felhasználható, megosztható és újraközölhető, feltéve, hogy az eredeti szerző és a közlés helye, illetve a CC License linkje és az esetlegesen végrehajtott módosítások feltüntetésre kerülnek. (SID_1) 